\title{
THE PURIFICATION AND PROPERTIES OF AN ALCOHOL DEHYDROGENASE FROM MOUSE LIVER*
}

\author{
RALPH J. KESSLER $†$ AND WILLIAM J. FERRELL $\ddagger$ \\ Department of Pathology, The University of Michigan, Ann Arbor, Michigan 48104, \\ U.S.A.
}

(Received 20 August 1973)

\begin{abstract}
I. An alcohol dehydrogenase (alcohol : NAD oxidoreductase, EC (I - I - I) was isolated from the supernatant fraction of mouse liver and purified 206-fold.

2. A number of aliphatic aldehydes, ranging from acetaldehyde to octadecanal, as well as benzaldehyde and isobutanal, were capable of being reduced by the enzyme. $K_{m}$ values ranged from $9.9 \times 10^{-4}$ to $2.5 \times 10^{-8} \mathrm{M}$.

3. Cetyl alcohol was slowly oxidized to the aldehyde by the enzyme in the presence of $\mathrm{NAD}^{+}$. However, attempts to oxidize ethanol were unsuccessful.

4. The enzyme showed a $\mathrm{pH}$ optimum at $\mathrm{pH} 6.8$ with irreversible denaturation occurring below $\mathrm{pH} 5$ and above $\mathrm{pH} 9$.
\end{abstract}

In recent years the existence of free fatty aldehydes has been demonstrated in several mammalian tissues (Gilbertson, Ferrell \& Gelman, 1967; Radloff \& Ferrell, 1970; Gilbertson, Johnson, Gelman \& Buffenmyer, I972), in luminous bacteria (Ferrell, Kessler \& Drouillard, I97I) and various fruits (Schmid \& Bandi, r 969 ; Ferrell \& Drouillard, 1970; Starratt \& Harris, 1971). Fatty alcohols have also been shown to exist in mammalian tissues (Takahashi \& Schmid, 1970; Bandi \& Mangold, I971).

Experiments (Schmid \& Takahashi, 1970) studying the incorporation of radioactively labelled palmitic acid and cetyl alcohol into plasmalogens have shown that when palmitic acid was the precursor, radioactively labelled long chain alcohols could be isolated from the lipid extract. Cetyl alcohol was readily oxidized to the fatty acid. However, attempts to isolate an intermediate aldehyde were unsuccessful.

* This study was conducted while the authors were associated with the Department of Chemistry, University of Detroit, Detroit, Michigan.

+ Submitted in partial fulfillment of the requirements for the degree of Ph. D. (Chemistry).

Present address: The Enzyme Institute, University of Wisconsin, Madison, Wisconsin 53706, U.S.A.

$\ddagger$ To whom reprint requests should be made.
Decanaldehyde and palmitaldehyde, as well as many aromatic aldehydes, were shown to act as substrates for an aldehyde reductase from bovine brain (Tabakoff \& Erwin, 1970).

The enzymic reduction of palmitic acid to cetyl alcohol has been shown to occur in microsomes using NADPH, ATP, CoA and $\mathrm{Mg}^{++}$. The reverse reaction required NAD, rather than NADP, and the additional cofactors were unnecessary (Snyder \& Malone, i970).

Broccoli leaves contain an enzyme or enzymes with the ability to reduce palmitaldehyde to the corresponding alcohol using NADPH (Kolattukudy, 197I). The enzyme was inhibited by $p$-chloromercuribenzoate (CMB).

The reduction of fatty acids to primary alcohols has been demonstrated with a cell free preparation from Euglena gracilis. ATP, $\mathrm{CoA}$ and NADH were required and an aldehyde intermediate was trapped (Kolattukudy, 1970).

An alcohol dehydrogenase from Candida tropicalis (Lebeault, Roche, Duonjak \& Azoulay, 1970) was active towards a number of aliphatic alcohols. The enzyme failed to react with very short chain alcohols.

It has been shown (Stoffel, Sticht \& LeKim, I968; Stoffel, LeKim \& Meyn, I970) 
that palmitaldehyde, released as the primary cleavage product from sphinganine-Iphosphate, was eventually incorporated into the alkenyl ether chain of plasmalogens. Furthermore, the palmitaldehyde was not oxidized to palmitic acid but was first reduccd to cetyl alcohol.

An alcohol dehydrogenase, requiring either NADH or NADPH, and found in the supernatant of rat liver, has been purified (Markovic, Theorell \& Rao, I971). Several aliphatic aldehydes were found to be active substrates, the highest specificity being obtained with hexanal.

Evidence for a CoA-linked dehydrogenase in bovine heart, which could convert fatty acids to fatty aldehydes has been presented (Ferrell, I 967) and recently the enzyme was isolated and partially purified (Johnson \& Gilbertson, 1972).

Earlier work from this laboratory (Ferrell \& Kessler, 1971) presented evidence that mouse liver contains at least two alcohol dehydrogenase (alcohol : NAD oxidoreductase, EG I . I . I) capable of reducing fatty aldehydes to fatty alcohols. One of these enzymes was located in the supernatant and required $\mathrm{NADH}$, while the other required NADPH and was located in the particulate fraction.

This paper describes the isolation, purification and properties of the supernatant alcohol dehydrogenase.

\section{MATERIALS AND METHODS}

\section{Enzyme Preparation and Purification}

Thirty-day-old Swiss-Webster male mice were used throughout these experiments. The mice were killed by cervical dislocation, the liver removed, weighed and homogenized for 1 minute with 5 volumes $(\mathrm{w} / \mathrm{v})$ of cold $\left(4^{\circ} \mathrm{C}\right) 0.25 \mathrm{M}$ sucrose in a Waring blender at full speed. This homogenate was separated into supernatant and particulate fractions by centrifugation at $100,000 \mathrm{~g}$ for 75 minutes at $4^{\circ} \mathrm{C}$.

Precipitation with ammonium sulfate was accomplished by adding solid ammonium sulfate (Mann Research Labs, New York.) to $20 \mathrm{ml}$. aliquots of the supernatant solution. After the ammonium sulfate was completely dissolved, the solution was allowed to stand for 30 minutes at $4^{\circ} \mathrm{C}$ with intermittent stirring. Precipitates were removed by centrifugation. The fractions insoluble at 0.3 saturation (fraction 1 ), soluble at 0.3 but insoluble at 0.6 (fraction 2) and soluble at 0.6 but insoluble at 0.9 (fraction 3 ), were collected and dissolved in a minimum amount of $0.9 \%$ saline. Ammonium sulfate was removed by passing each fraction through a $1 \times 15 \mathrm{~cm}$ column of Sephadex G25 (Pharmacia Fine Chemicals, Piscataway, N.J.).

The supernatant was also heated in a $70^{\circ} \mathrm{C}$ water bath for 15 minutes and then cooled in ice. Precipitated protein was removed by centrifugation at $20,000 \mathrm{~g}$ for 20 minutes. The resulting supernatant solution was vacuum dialyzed against glass distilled water at $5^{\circ} \mathrm{C}$ until the volume was reduced by $80 \%$. This concentrated solution was recentrifuged to remove any solids and the supernatant stored frozen until used.

Diethylaminoethyl cellulose (DEAE) and carboxylmethyl cellulose (CM) were obtained from Carl Scheicher \& Schuell, Keene, N.H. Serva GE cellulose was obtained from Gallard-Schesinger Chemical Corp., Carl Place, N.Y. After washing with $0.5 \mathrm{~N} \mathrm{NaOH}$ and $0.5 \mathrm{~N} \mathrm{HCl}$ the celluloses were washed with phosphate buffer and finally suspended in buffer and adjusted to the appropriate $\mathrm{pH}$.

Sephadex G25, G75, Gi5o and $Q \Lambda E-\Lambda_{-50}$, were allowed to swell in $0_{0} \cdot 0_{5} \mathrm{M}$ phosphate buffer at $\mathrm{pH} 6.8$ for $2,12,4^{8}$ and 14 hours respectively. Fines were decanted before the slurries were packed into $I \times 30 \mathrm{~cm}$. columns. Elution was accomplished under gravity flow using $0.05 \mathrm{M}$ phosphate buffer at $\mathrm{pH} 6 \cdot 8$.

The cellulose and Sephadex ion exchangers were eluted using either stepwise or linear salt gradients or a stepwise $\mathrm{pH}$ gradient. The eluent was monitored at $280 \mathrm{~nm}$. and $1 \mathrm{ml}$. fractions were collected and assayed for enzyme activity.

\section{Enzyme Assays}

Enzyme assays were carried out either spectrophotometrically or fluorometrically. A unit of activity is defined as the ability to reduce 1 nanomole of aldehyde per minute. For the spectrophotometric assay, the amount of reduced or oxidized pyridine nucleotide coenzyme at $340 \mathrm{~nm}$. was measured as a function of time using a Beckman Model DB spectrophotometer, equipped with a recorder. The total volume of the solution was $2.3 \mathrm{ml}$. in a $1 \mathrm{~cm}$. square quartz cuvette. All assays were run at room temperature $\left(23^{\circ} \mathrm{C} \pm \mathrm{I}^{\circ} \mathrm{C}\right)$. One $\mathrm{ml}$. of potassium phosphate buffer ( $0.1 \mathrm{mmole}$ ) and 0.3 moles of NADH were used in each assay except where noted in legends. The $\mathrm{pH}$ of the buffer was 6.8 except where noted. Enzyme solution $(0 \cdot 1 \mathrm{ml}$.) was added along with sufficient glass distilled water to bring the total volume to $2.3 \mathrm{ml}$. Aldehydes were dissolved in sufficient Tween 20 and water to make a clear solution. Enzyme reactions were initiated by the addition of substrate. The enzyme solution was standardized for $\mathrm{ADH}$ activity at the beginning and end of each day by checking its activity 
against a standard amount of $\mathrm{C}_{14}$ aldehyde. Tween 20 showed no effect on the kinetics being studied.

For the second method an Eppendorf Photometer with a fluorescence attachment was used with a HG 313-366 filter for excitation and a HG 400-3000 filter for emission. The basic procedure was the same as just described except that the total volume was increased to $3 \mathrm{ml}$., with distilled water, and reactions were initiated by the addition of NADH or NADPH.

In all experiments kinetic data were calculated from the initial slope rate after 5 minutes of reaction. To minimize the error in these measurements, every attempt was made to keep the initial slope between $30^{\circ}$ and $60^{\circ}$ by adjustments in enzyme concentration.

The NADH, NADPH and NAD were purchased from General Biochemicals (Chagrin Falls, Ohio). Fatty aldehydes used in this study were synthesized (Ferrell \& Yao, 1972) and cetyl alcohol was obtained from Sigma (St. Louis, Mo.). All substrates were purified by TLC (Gilbertson et al., r 967). Samples of $n$-butanal, isobutanal and acetaldehyde were purified by distillation and the purity checked by GLC on EGSS-X at temperatures ranging from $30^{\circ} \mathrm{C}$ to $180^{\circ} \mathrm{C}$. Only aldehydes with purities of greater than $99 \%$ were used.

As a precaution against oxidation, all solutions of aldehyde, Tween 20 and water were made fresh daily. It was sometimes necessary to warm the aldehyde solutions under tap water in order to obtain a clear solution. All reagents, except the enzyme, which was kept in ice, were allowed to reach room temperature before use.

Quantitative analysis of the different aldehydes was accomplished as described previously (Ferrell, Radloff \& Jackiw, 1969) from aliquots of the various aldehyde solutions.

Protein concentrations were determined spectrophotometrically (Waddell, 1956).

\section{RESULTS}

\section{i. Enzyme Isolation and Purification}

Following precipitation with ammonium sulfate, the overall recovery of $\mathrm{ADH}$ activity in the various fractions was around $70 \%$. This activity was found to be distributed between fraction 2 and fraction 3. Fraction 2 contained $40 \%$ of the recovered activity while fraction 3 contained $60 \%$. By adjusting fraction 3 so that it contained all material soluble at 0.55 saturation, but insoluble at 0.9 saturation, the percentage of enzyme activity in this fraction could be increased to $68 \%$. Further attempts to purify the enzyme by ammonium sulfate precipitation were halted when it was found that the precipitated fractions slowly became inactivated when stored either frozen or cold.

The heat inactivation study of the supernatant was carried out to assess the presence of more than one NADH-dependent $\mathrm{ADH}$ enzyme in the supernatant. The results, given in Frg. I, suggest that only one NADHdependent long chain alcohol dehydrogenase is present in the supernatant, as shown by the

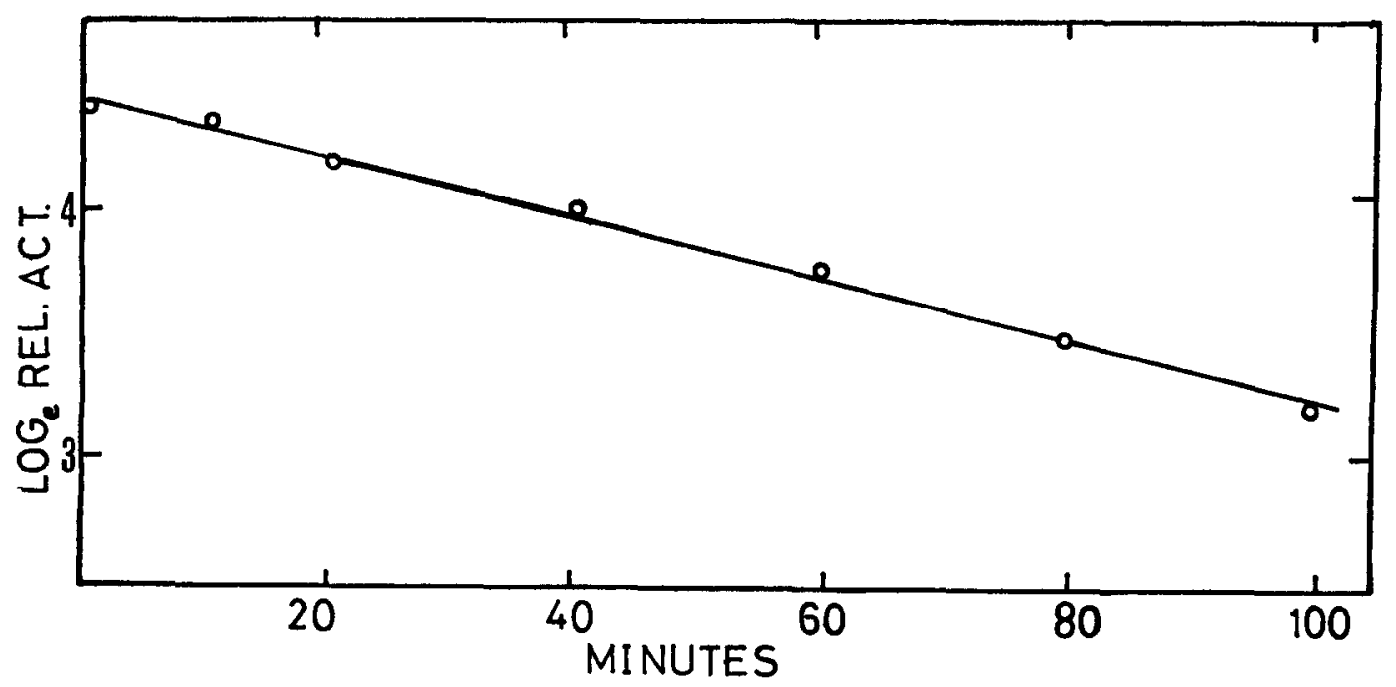

Fig. 1.- - Heat inactivation study of mouse liver supernatant at $70^{\circ} \mathrm{C}$. Reaction rate was determined by following the oxidation of $\mathrm{NADH}$ at $24^{\circ} \mathrm{C}$ as described in the text, using tetradecanal as substrate. 
first order inactivation curve. In addition, the data shows the enzyme to be quite heat stable. Heating the supernatant to $70^{\circ} \mathrm{C}$ for 15 minutes resulted in only a $4 \%$ loss in activity. However, large amounts of extraneous protein were precipitated, increasing the specific activity of the supernatant by a factor of $2 \cdot 8$. Therefore, the heat treatment was used as the first purification step for subsequent preparations. Vacuum dialysis of the supernatant obtained after heating was carried out to concentrate the enzyme activity. The dialysis step also succeeded in precipitating extraneous protein, thereby increasing the specific activity by an additional factor of approximately 2 . The recovery of total enzyme activity was $86 \%$. Assay of the dialysate revealed that none of the enzyme had passed across the membrane. Adding dialysate to the dialysed solution also failed to regain the original enzyme activity. Thus, the activity was probably lost by irreversible enzyme denaturation, although it may have been precipitated with the extraneous protein.
After dialysis the enzyme solution remained stable to storage at $-20^{\circ} \mathrm{C}$.

Attempts to purify the enzyme by chromatography on cellulose derivatives were hampered because the enzyme could not be bound to the celluloses at a $\mathrm{pH}$ at which it would retain activity. On CM cellulose the enzyme could only be bound at a pH of 5 or lower, and at this $\mathrm{pH}$ the enzyme was irreversibly denatured (See pH curve, Fic. 2).

DEAE cellulose was also unsuccessful in binding the enzyme over a $\mathrm{pH}$ range of 6 to 8.5 . GE cellulose was found to bind the enzyme at a $\mathrm{pH}$ of 9.5 or higher. However, the enzyme was partially denatured at this $\mathrm{pH}$.

The enzyme was purified further by applying $2 \mathrm{ml}$. of the dialyzed solution, buffered to $\mathrm{pH} 8.5$ with phosphate buffer, to a DEAE column also buffered at $\mathrm{pH} 8 \cdot 5$. The column was then eluted with glass distilled water. Assaying the fractions eluted from the column showed most of the activity to be located in the first few $\mathrm{ml}$.

The purification obtained after the various steps is summarized in Table I.

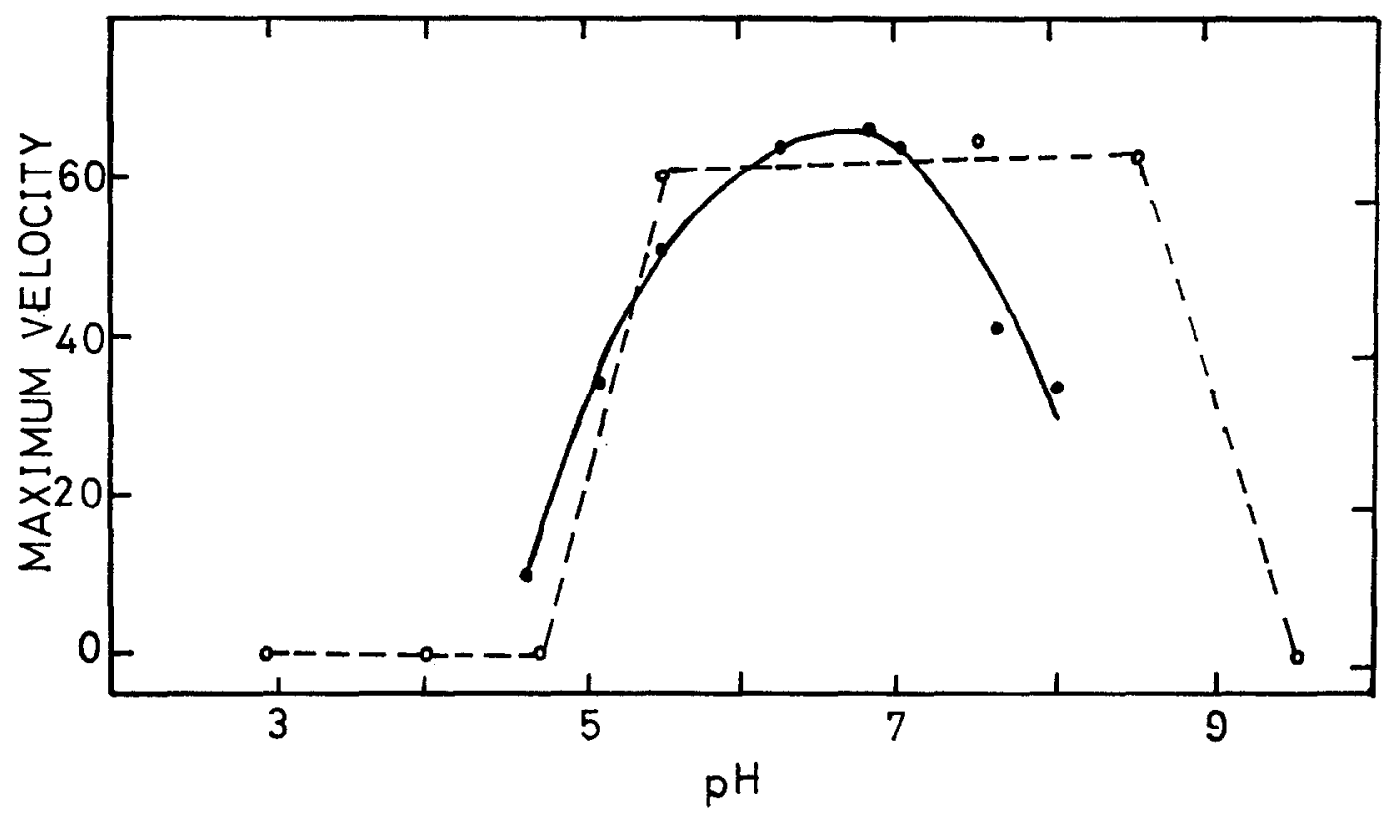

FIG. 2.-Plot of maximum velocity against $\mathrm{pH}$ for the substrate $n$-butanal is indicated by the solid circles (O). The open circles $(O)$ indicate the effect of preincubation of the enzyme at the indicated $\mathrm{pH}$ followed by assay at $\mathrm{pH}$ 7. The rate of reaction was determined by following the oxidation of NADH as described in the text. For these experiments $3 \mu$ moles of NADH was used. 
Table I.-Mouse Liver Alcohol Dehydrogenase: Summary of Purification

\begin{tabular}{|c|c|c|c|c|}
\hline Fraction & $\begin{array}{c}\text { Total } \\
\text { Actrviry* }\end{array}$ & $\begin{array}{l}\text { Specific } \\
\text { Actrvity }\end{array}$ & $\begin{array}{l}\text { Purification } \\
(- \text { fold })\end{array}$ & YIELD $(\%)$ \\
\hline \multicolumn{5}{|l|}{ Total } \\
\hline Homogenatef & 20 & $0 \cdot 05^{8}$ & $1 \cdot 0$ & IOO \\
\hline Supernatant $100,000 \mathrm{~g}$ & 20 & 0.25 & $4 \cdot 3$ & 100 \\
\hline Supernatant after heating & $19 \cdot 2$ & 0.71 & $12 \cdot 2$ & 96 \\
\hline Supernatant after vacuum dialysis & I7 & $1 \cdot 2$ & $20 \cdot 6$ & $8_{5}$ \\
\hline DEAE column at $\mathrm{pH} 8.5$ & 12 & I $2 \cdot 0$ & 206 & 60 \\
\hline
\end{tabular}

* Expressed as nanomoles of tetradecanal reduced per minute.

+ Expressed as nanomoles of tetradecanal reduced per minute per microgram of protein.

$\ddagger$ Activity determined using $\left[\mathrm{T}-{ }^{14} \mathrm{C}\right]$ tetradecanal and an incubation procedure described previously (see Ferrell \& Kesler, 1971).

Attempts to purify the enzyme further by chromatography on Sephadex columns were also unsuccessful, again due to loss of activity.

Purified enzyme solutions were found to be unstable at room temperature. However, the stability could be increased by keeping the enzyme cold or frozen. After 3 days at $2^{\circ} \mathrm{G}$, the purified enzyme had lost $53 \%$ of its activity, while the frozen enzyme had lost only I $1 \%$. Due to this instability, the enzyme was stored frozen after the dialysis step and was further purified only when additional enzyme was required.

\section{Properties of the Enzyme}

The cofactor requirements of the enzyme have previously been investigated in vitro (Ferrell \& Kessler, I97I). These workers showed that the enzyme required a reduced

Table II.-Michaelis Constants for NADH AND NADPH

\begin{tabular}{llc}
\hline COENZYME & ALDEHYDE & $\begin{array}{c}K_{m} \\
(\mathrm{M})\end{array}$ \\
\hline NADH & $n$-butanal & $\mathrm{I} \cdot 2 \times 10^{-4}$ \\
NADPH & $n$-butanal & $3 \cdot \mathrm{I} \times 10^{-3}$ \\
NADH & dodecanal & $2 \cdot 2 \times 10^{-5}$ \\
NADPH & dodecanal & $4.9 \times 10^{-4}$ \\
\hline
\end{tabular}

The Michaelis constants for NADH and NADPH were determined from Lineweaver-Burk plots. The concentration of $n$-butanal was $2.2 \times 10^{-4} \mathrm{M}$ and the concentration of dodecanal was $3.8 \times 10^{-5} \mathrm{M}$. The reaction was carried out at $\mathrm{pH} 6.8$ at room temperature. The rate of the reaction was measured fluorometrically as described in the text. pyridine nucleotide, NADH being more effective than NADPH. These results were further substantiated here (Table II).

The effect of $\mathrm{pH}$ on the reduction of $n$-butanal was studied using NADH. Effects on the affinity of the enzyme were eliminated by using a series of substrate concentrations at each $\mathrm{pH}$ level assayed. From this data, the maximum velocity $\left(V_{\max }\right)$ for each $\mathrm{pH}$ level was calculated and plotted against $\mathrm{pH}$ as shown in Fig. 2. Optimum activity was obtained between $\mathrm{pH} 6$ and 7. A similar curve was obtained with tetradecanal.

The activity of the enzyme toward aldehydes of even and odd chain lengths from $\mathrm{C}_{2}$ to $\mathrm{C}_{18}$ was determined and the Michaelis constants $\left(K_{m}\right)$ and $V_{\max }$ values calculated for

Table III.-Michaelis Constants and Maximal VELOCITIES

\begin{tabular}{|c|c|c|}
\hline Substrate & $\begin{array}{c}K_{m} \\
(\mathrm{M})\end{array}$ & $\begin{array}{c}V_{\max } \\
\text { (nmoles aldehyde } \\
\text { reduced } / \mathrm{ml} . / \text { minute }\end{array}$ \\
\hline Acetaldehyde & $2 \cdot 2 \times 10^{-6}$ & 59 \\
\hline n-Butanal & $1 \cdot 1 \times 10^{-5}$ & 69 \\
\hline iso-Butanal & $9.9 \times 10^{-6}$ & 250 \\
\hline Dodecanal & $2.5 \times 10^{-6}$ & 26 \\
\hline Tetradecanal & $8.2 \times 10^{-6}$ & 28 \\
\hline Hexadecanal & $8.3 \times 10^{-6}$ & 14 \\
\hline Heptadecanal & $43 \times 10^{-6}$ & $1 \cdot 7$ \\
\hline Octadecanal & $3.3 \times 10^{-5}$ & $2 \cdot 3$ \\
\hline Oleylaldehyde & $2.2 \times 10^{-5}$ & 9 \\
\hline Linolyladehyde & $6.0 \times 10^{-6}$ & Io \\
\hline
\end{tabular}

Michaelis constants $\left(K_{m}\right)$ and maximum velocities $\left(V_{\max }\right)$ were determined by LineweaverBurk plots. The rate of reaction was measured spectrophotometrically as described in the text. 


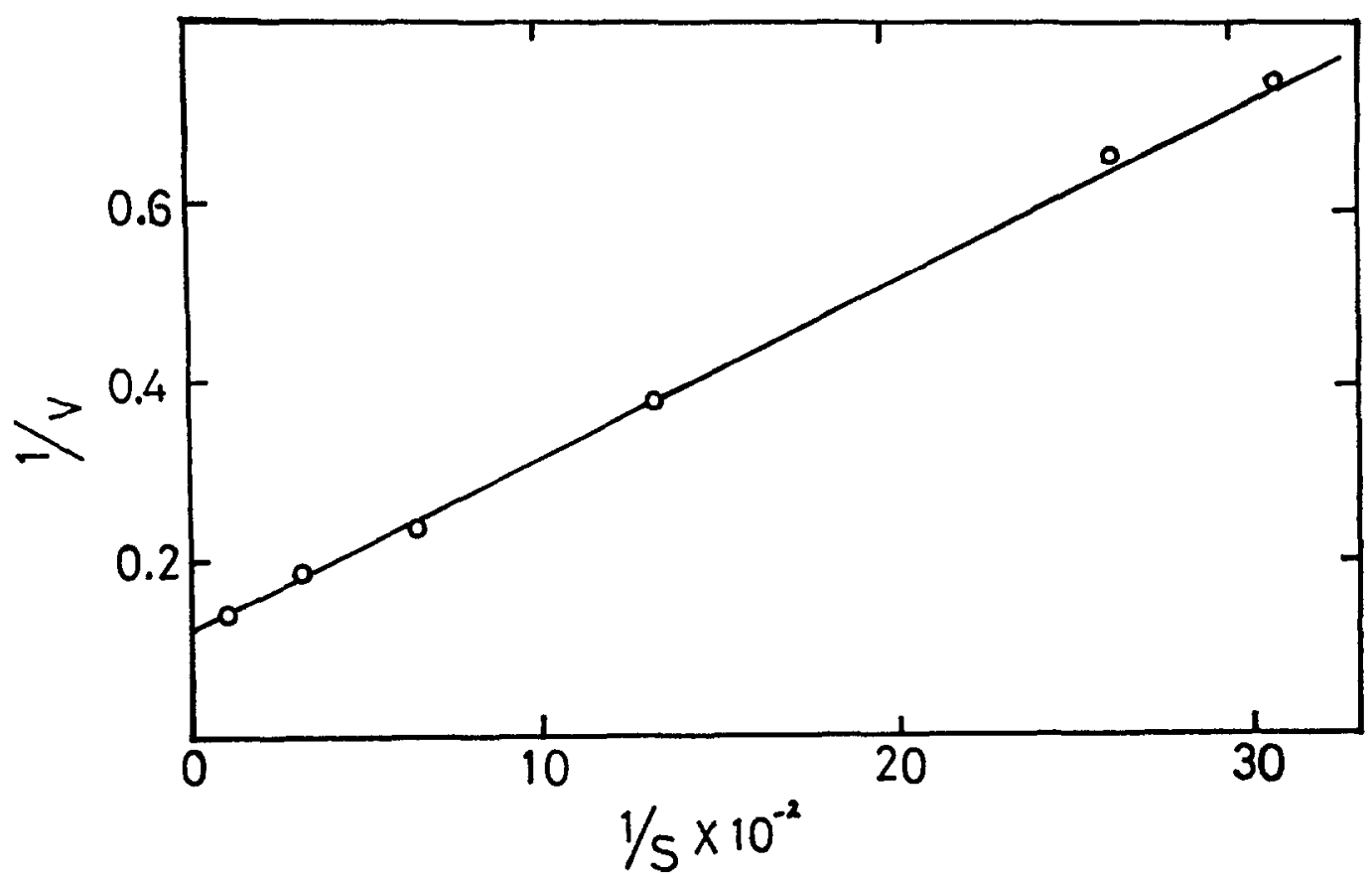

Frg. 5.-Lineweaver-Burk plot with cetyl alcohol. The rate of the reaction was determined by following the reduction of NAD as described in the text. $V$ equals nmoles of alcohol oxidized per $\mathrm{ml}$. of enzyme per minute.

has been described. This enzyme, obtained from mouse liver supernatant, was purified 206-fold. Attempts to purify the enzyme and to determine its molecular weight by gel filtration were unsuccessful due to loss of activity following chromatography. The complete lack of enzymatic activity suggests that some essential cofactor had been separated from the enzyme rather than a simple denaturation of the protein. However, recombination experiments, as well as adding glutathione and several different ions, were unsuccessful in restoring activity.

The differences in our purification procedure for the ADH from mouse liver and that described for rat liver ADH (Markovic et al., I97I) shows that different enzymes are involved. Their enzyme was purified by ammonium sulfate precipitation between 0.35 and 0.75 saturation, dialyzed, followed by application to a DEAE column and finally subjected to gel filtration on Sephadex Gr Ioo. The rat liver enzyme was relatively stable only at $\mathrm{pH} 8$ or higher and the optimal temperature for storage was $o^{\circ} \mathrm{C}$. Even under these conditions the enzyme lost over $50 \%$ of its activity in 4 days. Markovic et al. (197 I), suggested that the instability of the enzyme was due to oxidation of SH groups in the enzyme. Alcohols ranging from ethanol to cyclohexanol were found to be substrates for the enzyme. However, the reduction of aliphatic aldehydes to alcohols was not studied. A partiallypurified rat liver $\mathrm{ADH}$ was also prepared by ammonium sulfate precipitation between 0.55 and 0.85 saturation after concentration by a heating step at $5^{\circ} \mathrm{C}$ for 2 minutes (Stoffel et al., 1970).

In our experiments with mouse liver ADH it was found that purification by precipitation with ammonium sulfate was unsuitable due to the large loss of enzyme activity during storage of the precipitated fractions. The enzyme in the impure state was heat stable. Heating the solution containing the enzyme at $70^{\circ} \mathrm{C}$ for 15 minutes resulted in only a $4 \%$ loss of activity. However, after purifica- 
tion by DEAE chromatography, the enzyme was found to be heat sensitive and could be kept active only by refrigeration or freezing. This heat sensitivity could be due to the loss of a protective agent. In contrast to the purified enzymes from horse and rat liver, mouse liver ADH is more stable when frozen than under refrigeration. Our purified enzyme was found to be stable over a $\mathrm{pH}$ range of 6 to 8 .

The enzyme showed a wide substrate specificity. Aliphatic aldehydes such as acetaldehyde and butyraldehyde act as excellent substrates for the enzyme. Longer chain fatty aldehydes, up to $\mathrm{C}_{18}$, were found to be less readily reduced. The possibility of multiple enzymes has been suggested (Stoffel et al., 1970) to explain the kinetics of the reduction of aldehydes of different chain lengths. In the present study, all efforts to purify the enzyme failed to reveal the presence of more than one alcohol dehydrogenase in the supernatant. The results of the heat inactivation study also suggests that the enzyme activity was due to a single enzyme.

A review (Sund \& Theorell, I963) of studies on the kinetics of the liver ADH reaction reveals that the enzyme acts by forming all four binary complexes between the enzyme, NAD, NADH, and the aldehyde or alcohol. The binary complexes can then form two ternary complexes, containing substrate and coenzyme, in rapid equilibrium with each other. From the kinetic point of view, this is described as the Theorell-Chance mechanism (T.-C. mechanism).

In the present study it was found that equal reaction rates were obtained independent of whether the enzyme was preincubated with substrate or coenzyme, thereby supporting the view of the T.-C. mechanism.

The effect of $\mathrm{pH}$ on mouse liver $\mathrm{ADH}$ (FIG. 2) gave a fairly broad optimum between $\mathrm{pH} 6$ and 7 . If the enzyme followed the typical T.-C. mechanism one might expect changes in $\left[\mathrm{H}^{+}\right]$to influence the step where $\mathrm{H}^{+}$is being transferred. However, in our experiments preincubation of the enzyme at various pHs from 4 to Io, followed by an assay for activity at $\mathrm{pH} 7$, showed that, at $\mathrm{pH} 5$ or below and above $\mathrm{pH} 9$, irreversible denaturat on of the enzyme occurred. Thus it is felt that the observed $\mathrm{pH}$ optimum is due to irreversible denaturation and that the mechanism of mouse liver $\mathrm{ADH}$ may not be totally explained by the T.-C. mechanism.

Horse liver $\mathrm{ADH}$ has been reported (Sund \& Theorell, I963) to oxidize a variety of alcohols. The enzyme was also able to reduce various aldehydes and could oxidize formaldehyde and other aldehydes to the corresponding acids. Mouse liver ADH possesses the ability to oxidize cetyl alcohol. However, it showed no measurable activity with ethanol.

The enzyme showed a preference for NADH over NADPH by a factor of 4.8 , using dodecanal as substrate at a concentration of $3.8 \times 10^{-5} \mathrm{M}$. In contrast, horse liver $\mathrm{ADH}$ was only one-hundredth as active with $\mathrm{NADH}$ as NADPH. ADH isolated from broccoli leaves preferred NADPH to NADH by a factor of 5 -fold for the reduction of palmitaldehyde (Kolattukudy, I 97 I), whereas the rat liver enzyme showed no preference for either coenzyme (Stoffel et al., I970).

From the $K_{m}$ and $V_{\max }$ values (Table III) it is observed that, in general, $V_{\max }$ decreased with increasing chain length within the saturated, normal aliphatic aldehydes and that substrate inhibition occurred. The T.-C. mechanism is useful in looking at the effects of substrate inhibition. With horse liver $\mathrm{ADH}$, evidence favored the existence of a ternary E-NADH-alcohol complex as being responsible for substrate inhibition (Shore \& Theorell, I 966). The association of the alcohol with E-NADH was thought to be lipophilic in nature due to the increasing inhibition exhibited with increasing chain length.

In the present study, it was observed that substrate inhibition also generally increased with increasing chain length. This inhibition could be viewed as the result of the combination of the nonpolar part of the aldehyde with a lipophilic site of the E-NAD complex, which would otherwise interact with the nonpolar end of the alcohol, resulting in the formation of an E-NAD-aldehyde abortive complex. The same mechanism has been 
used to describe substrate inhibition of horse liver ADH (Shore \& Theorell, Ig66). The case of benzaldehyde is of particular interest and the Lineweaver-Burk plot is shown in Fig. 4. Here substrate inhibition is seen even at the lowest levels of substrate utilized, which could indicate that the aromatic aldehyde interacts very strongly with a lipophilic site of the E-NAD complex. Thus, it is felt that the effect of chain length on $V_{\max }$ (Table III) is a result of the increased ability of the enzyme to form the abortive complex similar to horse liver ADH (Shore \& Theorell, I966). The possibility that the decreasing values of $V_{\max }$ with increasing chain length could result simply from a shift in the limiting rate from dissociation of coenzyme to the dissociation of fatty alcohol product cannot be eliminated.

\section{ACKNowledgements}

This investigation was supported, in part, by a research grant from the U.S. Public Health Service, Grant HL-I336I-02, 03. The authors thank Dr. J. Shore, Ford Hospital, for the use of the Eppendorf Photometer and for helpful comments.

\section{REFERENCES}

Bandi, Z. L., \& Mangold, H. K. (I97I), 'Formation of long-chain alcohols in the gastrointestinal tract of the rat', FEBS Lett., 13, I98-200.

Ferreld, W. J. (1967), 'Studies on the natural occurrence and biosynthesis of free fatty aldehydes in cardiac muscle', (Ph.D. Thesis, University of Pittsburg). Des. Abs., 30, 1969.

Ferreld, W. J., Radloff, J. F., \& Jackiw, A. B. ( I 969), " Quantitative analysis of free and bound fatty aldehydes: optimum conditions for $p$-nitrophenylhydrazone formation', Lipids, 4, 278-282.

Ferrell, W. J., \& Droutllard, M. (1970), 'Long chain free fatty aldehydes in fruit lipids ', Physiol. Chem. Phys., 2, 168-1 7o.

Ferrell, W. J., \& Kessler, R. J. (1971), 'Enzymic relationship of free fatty acids, aldehydes and alcohols in mouse liver', Physiol. Chem. Phys., 3, 549-558.

Ferrell, W. J., Kessler, R. J., \& Drouillard, M. (I97I), "Identification of n-nonaldehyde in Photobacterium fisheri', Chem. Phys. Lipids, 6, I 31 I34.

Ferrell, W.J., \& Yao, K. C. (1972), 'Reductive and oxidative synthesis of saturated and unsaturated fatty aldehydes', 7. Lipid Res., 13, 23-26.

Gilbertson, J. R., Ferrell, W. J., \& Gelman, R. A. ( 1967 ), 'Isolation and analysis of free fatty aldehydes from rat, dog and bovine heart muscle', 7. Lipid Res., 8, 38-45.

Gilbertson, J. R., Johnson, R. C., Gelman, R. A., \& BuFfenMYer, C. (I972), 'Natural occurrence of free fatty aldehydes in bovine cardiac muscle', 7. Lipid Res., 13, 491499.

Johnson, R. C., \& Gilbertson, J. R. (1972), 'Isolation, characterization, and partial purification of a fatty acyl coenzyme A reductase from bovine cardiac muscle', F. Biol. Chem., 247, 699 I-6998.

KolAtTukudy, P. E. (1970), ' Reduction of fatty acids to alcohols by cell-free preparations of Euglena gracilis', Biochemistry, 9, $1095-1102$.

Koldatrukudy, P. E. (1971), 'Enzymatic synthesis of fatty alcohols in Brassica oleracea', Archs. Biochem. Biophys., 142, 701-709.

Lebeault, J. M., Meyer, F., Roche, B., \& ZaOUlay, E. (1970), 'Oxydation des alcools superieurs chez Candida tropicalis cultive sur hydrocarbures', Biochim. Binphys. Asta, 220, 386-395.

Lebeault, J. M., Roche, B., Duonjak, Z., \& Azoulay, E. (1970), "Alcool et aldehydedeshydrogenases particulaires de Candida tropicalis cultive sur hydrocarbures', Biochim. Biophys. Acta, 220, 373-385.

Lineweaver, H., \& Burk, D. J. (1934), 'The determination of enzyme dissociation constants', 7. Am. Chem. Soc., 56, 658-663.

Markovic, O., Theorell, H., \& Rao, S. (I97I), ' Rat liver alcohol dehydrogenase, purification and properties', Acta Chem. Scand., 25, 195205.

Radloff, I. F., \& Ferrell, W. J. (I970), 'Qualitative and quantitative analysis of free fatty aldehydes in human heart', Physiol. Chem. Phys., 2, 105-109.

Schmid, H. H. O., \& Bandi, P. C. (r969), ' $n$-Triacontanal and other long-chain aldehydes in the surface lipids of plants ', Hoppe-Seyler's Z. Physiol. Chem., 350, 462-466.

Schmid, H. H. O., \& Takahashi, T. (rg7o), 'Reductive and oxidative biosynthesis of plasmalogens in myelinating brain', 7. Lipid Res., 1x, 412-419.

Shore, J. D., \& Theorell, H. (1966), 'Substrate inhibition effects in the liver alcohol dehydrogenase reaction', Archs. Biochem. Biophys., II7, $375-380$.

SNyder, F., \& Malone, B. (1970), 'Enzymic interconversion of fatty alcohols and fatty acids', Biochem. Biophys. Res. Commun., 41, $13^{82-1} 3^{87}$.

Starratt, A. N., \& Harris, P. (197I), 'Occurrence of long-chain aldehydes in plant cuticular waxes', Phytochemistry., 10, $1855-1856$. 
Storfel, W., Sticht, G., \& LeKIM, D. (1968), - Degradation in vitro of dihydrosphingosine and dihydrosphingosine phosphates to palmitaldehyde and ethanolamine phosphate', HoppeSeyler's Z. Physiol. Chem., 349, 1745-1 748.

Storpel, W., LeKra, D., \& HeYN, G. (1970), 'Sphinganine (dihydrosphingosine), an effective donor of the alk-1-enyl chain of plasmalogens', Hoppe-Seyler's Z. Physiol. Chem., 35x, $875-883$.

Sund, H., \& Theorel., H. (1963), 'The Enzymes ', Vol. 7 pp. 25-83. New York: Academic Press.

TABakofr, B., \& ERwin, V. (1970), 'Purification and characterization of a reduced nicotinamide adenine dinucleotide phosphate-linked aldehyde reductase from brain', 7. Biol. Chem., 245, $3263-3268$.
TAKAhashi, T., \& Schmid, H. H. O. (1970), 'Long-chain alcohols in mammalian tissues', Chem. Phys. Lipids, 4, 243-246.

WADDELL, J. (1956), "A simple ultraviolet spectrophotometric method for the determination of protein', 7. Lab. Clin. Med., 48, 311317.

WITrer, A. (1960), "The binding of DPNH by liver alcohol dehydrogenase', Acta Chem. Scand., $x_{4}$, $717-1721$.

Key Word Index: Alcohol dehydrogenase, mouse liver, fatty aldehydes, fatty alcohols, kinetics, Sephadex, ion-exchange celluloses. 